\title{
Comparison of Chemical Composition and Colour Parameters of Different Mentha Genus Plants Grown under Organic Conditions
}

\author{
Živilè TARASEVIČIENE ${ }^{1}$, Aloyzas VELIČKA ${ }^{1 *}$, Elvyra JARIENE ${ }^{1}$, \\ Aurelija PAULAUSKIENE ${ }^{1}$, Anna KIELTYKA-DADASIEWICZ ${ }^{2}$, \\ Barbara SAWICKA ${ }^{2}$, Marek GAJEWSKI ${ }^{3}$
}

\author{
${ }^{1}$ Aleksandras Stulginskis University, Faculty of Agronomy, Agriculture and Food Sciences Institute, Studentu str. 11, Akademija, LT-53361 \\ Kauno district, Lithuania; zivile.taraseviciene@asu.lt;velikaalius@gmail.com ("*orrespondingauthor); \\ elvyra.jariene@asu.lt; aurelija.paulauskiene@asu.lt \\ ${ }^{2}$ University of Life Sciences in Lublin, Department of Plant Production Technology and Commodity, Akademicka 15, 20-950 Lublin, \\ Poland; akieltyka@poczta.onet.pl; barbara.sawicka@gmail.com \\ ${ }^{3}$ Warsaw University of Life Sciences - SGGW, Department of Vegetable and Medicinal Plants, Nowoursynowska 166, 02-787 Warsaw, \\ Poland;marek_gajewski@sggw.pl
}

\begin{abstract}
Mentha species are one of the world oldest and popular herbs, that are used in cosmetic and food industry, as well as tea for their medical properties. Due the consumer perception of ecological production and aromatic plants production waste utilization the objective of this work was to determine differences in chemical content and colour among different varieties and parts of Mentha plants ecologically grown in Lithuania. In mint leaves there were determined: content of essential oils, dry matter, soluble solids, ascorbic acid, crude fibre, crude ash, photosynthetic pigments and colour CIE L*a*b* parameters. In the case of mint plants stems, the same analyses were performed except ascorbic acid, soluble solids and colour. The highest content of essential oils were found in Mentha spicata L. 'Moroccan' and Mentha piperita L. 'Glacialis' leaves, while the least in Mentha suaveolens Ehrh. 'Variegata'. The content of essential oils in the stems was minor and did not depend on mint variety. Plant parts differ significantly in respect of chemical composition. Amount of dry matter in mint leaves and stems was very similar, while crude ash in the leaves was twice higher than in the stems. Content of crude fibre in the leaves did not differ significantly in all investigated varieties and was 3.6 times lower comparing with the stems. Average ratio of chlorophyll $a$ to $b$ in the leaves was equal to 2.78, while in stems equal to 2.83. The lightest was Mentha suaveolens 'Variegata', the darkest Mentha spicata L. 'Moroccan' and the greenest Mentha piperita L. 'Swiss' leaves. Mints and their parts differ in chemical content and can have widespread usage not only for production of high-value natural products but in addition as alternative fibrous biomass plants.
\end{abstract}

Keywords: aromatic plants; carotenoids; chlorophylls; essential oils; Mentha sp.

\section{Introduction}

The quality of herbs has a direct effect on their safety and efficacy (Triphaty et al., 2015). One of the major factors contributing to the poor quality of herbs is their contamination with pesticides, heavy metals, microbial load, polycyclic aromatic hydrocarbons (PAHs) and other environmental contaminants, such as fumigants (Who, 2011).
The organic method of cultivation of aromatic plants has the advantage that plants accumulate more biologically active substances than in the case of a conventional method (Young et al., 2005).

Recent studies have shown that consumer demand for foods from organic production systems is based on consumer perceptions that organic foods are more nutritious, better tasting, environmentally friendlier, healthier and safer than those produced conventionally (Jacob et al., 2008). These are the reasons why organic production should therefore be given a high profile. 
Plants of mint genus (Mentha sp.) belong to the Lamiaceae family. The genus is one of the most important aromatic plants genus in the world. By the amount of production it is only surpassed by essential oils extracted from vanilla and citrus plants (Doymaz, 2006). Pharmaceutical and cosmetic industries used more than 10,000 tonnes of natural menthol annually (Gupta et al., 2017).

Mentha genus comprises 20-30 species, while in Lithuania grows about 11. Many kinds of this genus plants are used in pharmacy, perfumery, culinary and also in agronomy in plant protection (Raja, 2012). Mentha $\times$ aquatica L., Mentha $\times$ canadensis L., Mentha $\times$ spicata L. and their hybrids - Mentha $\times$ gracilis Sole., Mentha $\times$ piperita L. and Mentha $\times$ villosonervata Opitz. are the most economically important plants (Tucker, 2007). Mint leaves are refreshing, with antispasmodic, anti-asthmatic, sweat promoting, anti-inflammatory properties (Božović et al., 2015). Mint species differ not only by appearance or usage, but also by chemical composition. Plants of this family are one of the most important sources not only of essential oils but also of extracts with high antioxidant activity (Zhang and Wang, 2001). The main compounds with the antioxidant properties in mints are phenols, ascorbic acid and carotenoids (Senge, 1993; Capecka et al., 2005). The quantity of biologically active substances in the plants depends on genotype and postharvest treatments. Hussain et al. (2010) determined that amount of essential oil depended on species and cultivation time of mint. The authors found that amount of essential oil in $M$. arvensis was $17.0 \mathrm{~g} \mathrm{~kg}^{-1}$, M. piperita $12.2 \mathrm{~g} \mathrm{~kg}^{-1}$, M. longifolia $10.8 \mathrm{~g}$ $\mathrm{kg}^{-1}$ and M. spicata $12.0 \mathrm{~g} \mathrm{~kg}^{-1}$ in summer grown plants, respectively $9.20,10.5,7.00$ and $9.50 \mathrm{~g} \mathrm{~kg}^{-1}$ in the winter crops. Essential oil accumulation in Mentha plants is also depended from soil and climate conditions, used agricultural practices (Chand et al., 2004; Mahboobeh et al., 2014; Golparvar and Hadipanah, 2016; Kahkashan et al., 2016).

Mentha spicata L. plants are rich in carvone, some cultivars have a high content of volatile oils and possess antifungal, antiviral, antimicrobial and insecticide activities (Elansary and Ashmawy, 2013). Mentha suaveolens Ehrh., previously named $M$. rotundifolia (L.) Huds, have very mild and slightly minty aroma. According to Sulieman et al. (2011), mint leaves have $6.2 \%$ of dietary fibre and $3.8 \%$ of ash. Mint plants are also rich in microelements. Leave colour is one of the most important aromatic plants quality indicator (Straumite et al., 2015). Such pigments as carotenoids and chlorophylls are responsible for colour parameters. Colour parameters are important for fresh-cut and processed herb plants produce. During processing (drying) of herbs colour changes from bright green to olive brown as the result of degradation of chlorophylls. It leads to the loss of magnesium ion and chlorophyll conversion to pheophytin (Gaur et al., 2007). Chlorophyll is the green tetrapyrrole plant pigment which acts as a photoreceptor of light energy in the photosynthesis (Kumar and Sinha, 2004). Chlorophyll content depends on such factors, as water availability, amount of nutrients, light intensity, air pollution and vegetation period. In addition, plant species and position of leaves affect the amount of chlorophyll (Gond et al., 2012).

In green plants tissues, chlorophylls are accompanied by carotenoids. More than 700 naturally occurring carotenoids have been identified and in plants, they perform photoprotective functions during photosynthesis and provide substrates for biosynthesis of the plant growth regulator abscisic acid (Niyogi, 2000; Britton et al., 2004; Nambara and Marion-Poll, 2005). Carotenoids act as photosensitizers in conjunction with chlorophyll (Zollinger, 1991). There are qualitative and quantitative differences of carotenoids depending on the plant species and organs.

After the usage of leaves of herbaceous plants for teas, extracts and other purposes the stems and other worthless parts as distilled lignocellulosic biomass are attributed as waste. The exploitation and utilization of waste materials generated by agricultural and food processing industry induce the investigation of the chemical content of different plant parts (Reis et al., 2012; Roselló-Soto et al., 2015; Shahidi and Ambigaipalan, 2015). Parts of different aromatic plants differ in chemical content, therefore, its usage can be different. The wastes resulting from processing, packaging and cultivation of packaged fresh herbs and the distilled lignocellulosic biomass of aromatic plants is a renewable, inexpensive source of primary feedstock for valorisation into liquid fuels and high value commercial products (Lin et al., 2014, Prakash et al., 2018). Fardad et al. (2018) states, that primary results from mesophilic anaerobic digestion of aromatic plants including mint wastes show that they are able to produce biogas and it is possible to recover methane as a source of renewable energy from these wastes instead of burning or burying them.

The difference in the chemical composition of the various parts of the plant and different mint species and kinds, the consumer trust in the ecological demand for products, and the possibility of using aromatic plant waste as secondary raw materials and developing waste-free production have led to that the objective of this work was to determine differences in chemical content and colour among different varieties and parts of ecologically grown Mentha plants.

\section{Materials and Methods}

\section{Biologicalmaterial}

The research was carried out in 2014-2015 at Aleksandras Stulginskis University in Lithuania. M. spicata 'Moroccan', M. piperita 'Glacialis', M. piperita 'Swiss', $M$. suaveolens Ehrh., M. gentilis 'Ginger', M. suaveolens 'Variegata' two-year old plants were grown in certified organic farm certificate number SER-K-17-01989, in the Panevezys district of Lithuania field location $\left(55^{\circ} 47^{\prime} 24.6^{\prime \prime} \mathrm{N} ; 24^{\circ} 26^{\prime} 28.7^{\prime \prime} \mathrm{E}\right)$ and harvested at 2014 in the first decade of August, just before flowering. Chemical content analyses were performed during 2014-2015. Prepared samples till the analyses were stored at the $-80^{\circ} \mathrm{C}$ temperature.

From each mint variety field $\left(10 \mathrm{~m}^{2}\right) 25$ plants were used for biometrical measurements. The height of plants was measured, leaves separated from stems and width and length of leaves were measured. 
94

\section{Climatic conditions}

In assessing temperature and moisture conditions nine scale classification of Sielianinov hydrothermal coefficient (k) was used, which, according to Skowera and Puła (2004): $\mathrm{k} \leq 0.4$ extremely dry, $0.4<\mathrm{k} \leq 0.7$ very dry, $0.7<\mathrm{k} \leq 1.0$ dry, $1.0<\mathrm{k} \leq 1.3$ quite dry, $1.3<\mathrm{k} \leq 1.6$ optimal, $1.6<\mathrm{k} \leq$ 2.0 quite wet, $2.0<\mathrm{k} \leq 2.5$ wet, $2.5<\mathrm{k} \leq 3.0$ very wet, $\mathrm{k}>$ 3.0 extremely wet. Climatic conditions in 2014 of mints vegetation period till the harvest is presented in the Table 1.

\section{Chemical content}

Essential oil was extracted by hydro distillation method, using Clevenger type apparatus boiling $25 \mathrm{~g}$ of sample for 4 hours (Lst En Iso 6571).

Dry matter was determined by weighting $3 \mathrm{~g}$ of mints samples and dried till the constant weight at $105^{\circ} \mathrm{C}$ in the drying oven (Termaks TS 800, Norway). For determination of the amount of crude ash $5 \mathrm{~g}$ of samples were weighed and burned for 3.5 hours at the temperature of $550^{\circ} \mathrm{C}$ in muffle furnace (Nabertherm LE 6/11/B 150, German). Amount of fibre was determined by Weender method (Methodenbuch, 1983-1999).

Soluble solids only in mint leaves were measured by digital refractometer (Atago, Japan) as well as ascorbic acid content was determined by titrimetric method, using 2,6dichlorphenolindophenol (Lst Iso 6557-2:2000).

Chlorophyll $a$ and $b$ and total carotenoids in fresh mint leaves were determined by double ray UV-Vis spectrophotometer UVS-2800 (Labomed Inc., USA), by reading of the absorbance at 470,645 and $662 \mathrm{~nm}$, using a glass cuvette. The content of chlorophylls and carotenoids were calculated according to (Wellburn, 1994). For pigments determination $0.4 \mathrm{~g}$ of mint samples were homogenized and extracted with acetone, using magnetic stirrer at $700 \mathrm{rpm}$ for 15 minutes. After the separation of the supernatant, the extraction was repeated (Straumite $e t$ al., 2015).

\section{Physical parameters}

Colour was detected by the spectrophotometer ColorFlex (Hunter Associates Laboratory Inc., USA), assessing coordinates $\mathrm{L}^{*}$ (lightness/darkness), $\mathrm{a}^{*}$ (redness/greenness), $\quad b^{*} \quad$ (yellowness/blueness). The instrument was standardized with black and white tiles. The chroma $\left(\mathrm{C}^{*}=\left(\mathrm{a}^{* 2}+\mathrm{b}^{* 2}\right)^{1 / 2}\right)$ and hue angle $\left(\mathrm{h}^{\circ}=\mathrm{atan}\left(\mathrm{b}^{*} / \mathrm{a}^{*}\right)\right.$ were also calculated (McGuiere, 1992).

\section{Statistical analysis}

All analytical measurements were made in triplicates. Statistical analysis was performed using one-way analysis of variance (ANOVA) (Statistica 10, StatSoft, USA). Fisher's test was applied to assess significant differences between the samples at $\mathrm{p}<0.05$.

Pearson's linear correlation coefficient $(\mathrm{p}<0.05)$ was calculated to assess the reliance between values.

\section{Results and Discussion}

\section{Biometrical parameters}

The data in the (Table. 2) show that biometrical parameters of mint plants differed significantly. Biometrical parameters of leaves did not depend on plant height. The highest were Mentha piperita 'Glacialis' and 'Swiss' plants. The biggest leaf length and width was of Mentha suaveolens Ehrh. plants. It was determined positive moderate correlation (0.681) between the high of mints and amount of fibre in the stems.

\section{Chemical content}

The main indicator of the quality of aromatic plants is the amount of essential oils which depends on species, origin, soil and climatic conditions, plant age and agricultural practice.

Table 1. Climatic conditions of mints vegetation period in 2014

\begin{tabular}{ccccc}
\hline Month & $\begin{array}{c}\text { Rainfall } \\
(\mathrm{mm})\end{array}$ & $\begin{array}{c}\text { Temperature } \\
\left({ }^{\circ} \mathrm{C}\right)\end{array}$ & $\begin{array}{c}\text { Hydrothermal coefficient } \\
\text { of Sielianinov }\end{array}$ & $\begin{array}{c}\text { Classification of } \\
\text { the month* }\end{array}$ \\
\hline March & 92.0 & 4.5 & - & - \\
\hline April & 74.0 & 8.6 & - & - \\
May & 131.0 & 13.0 & 1.8 & quite wet \\
June & 114.0 & 14.3 & 2.0 & quite dry \\
July & 61.0 & 19.9 & 1.1 & wet \\
August & 206.0 & 17.4 & quite dry \\
\hline
\end{tabular}

${ }^{*}$ Classification of the month according to Sielianinov in the modification of Skowera and Puła (2004)

Table 2. Biometrical parameters of Mentha plants

\begin{tabular}{|c|c|c|c|}
\hline Species/variety & Plant height $(\mathrm{cm})$ & Leaf length $(\mathrm{mm})$ & Leaf width $(\mathrm{mm})$ \\
\hline Mentha spicata 'Moroccan' & $62.65 \pm 6.04 \mathrm{a}^{*}$ & $30.80 \pm 6.26 b$ & $10.20 \pm 1.48 c$ \\
\hline Mentha piperita 'Glacialis' & $90.86 \pm 10.41 \mathrm{~b}$ & $48.80 \pm 6.53 \mathrm{ab}$ & $14.80 \pm 2.94 \mathrm{ac}$ \\
\hline Mentha gentilis 'Ginger' & $75.42 \pm 10.51 \mathrm{~d}$ & $49.80 \pm 11.64 \mathrm{ab}$ & $18.40 \pm 2.07 b c$ \\
\hline Menthapiperita 'Swiss' & $90.82 \pm 11.70 \mathrm{~b}$ & $56.40 \pm 3.05 b$ & $22.20 \pm 7.66 b$ \\
\hline Mentha suaveolens Ehrh & $58.24 \pm 8.39 a$ & $64.00 \pm 15.57 b$ & $60.80 \pm 8.70 \mathrm{~d}$ \\
\hline Mentha suaveolens 'Variegata' & $17.07 \pm 5.67 \mathrm{c}$ & $36.00 \pm 8.69 \mathrm{a}$ & $20.60 \pm 5.68 \mathrm{ab}$ \\
\hline
\end{tabular}

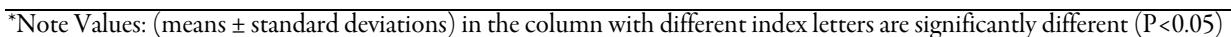


The highest amounts of volatile compounds were found in Mentha spicata 'Moroccan' and Mentha piperita 'Glacialis' leaves, while the least in Mentha suaveolens 'Variegata' (Fig. 1). It was determined only minor amount of essential oil in mint stems and it did not differ significantly among different mint varieties (Fig.1).

The highest content of dry matter was found in Mentha piperita 'Glacialis' and Mentha piperita 'Swiss' leaves (Table 3).

The difference between the highest and the least content of dry matter in leaves of investigated mint plants was 6.05 percent units.

In stems of Mentha piperita 'Swiss', the amount of dry matter was the highest while in Mentha suaveolens 'Variegata' stems the least (Table 3). According to (Grzeszczuk and Jadczak, 2009) dry matter content in Mentha piperita ranged from $20.35 \%$ to $24.24 \%$. It was established positive strong correlation between amount of essential oil content in mints leaves and amount of leaves dry matter $(0.827)$ as well as stems $(0.862)$.

Accumulation of crude ash was higher in mint leaves comparing with stems, while in the case of crude fibre the opposite tendency was found (Table 3).
Mentha suaveolens 'Variegata' leaves and stems were the richest in crude ash. There were no significant difference in the amount of crude fibre in leaves of different varieties of mint. In stems of Mentha suaveolens 'Variegata' and Mentha gentilis 'Ginger' amount of crude fibre was the least, while in Mentha piperita 'Swiss' was higher. Saeed et al. (2014) determined 2-3 times smallest content of crude ash in $M$. piperita leaves $3.12 \%$ and 2 times of crude fibre $6.12 \%$. According to Devi et al. (2018) in M. arvensis was 21.03\% of crude fibre and $9.38 \%$ of crude ash.

According to Godin et al. (2013) most suited for combustion alternative crops present the lowest content of mineral compounds, and for bioethanol conversion have high contents of total carbohydrates. Based on the analysis of the main components of the chemical composition it can be stated that M. piperita 'Swiss' could be potentially the most suitable for the production of biofuels due to the highest fiber content and the lowest amount of ash in stems.

The content of soluble solids is one of the most important quality indicator of plants. The highest amount of soluble solids was found in Mentha piperita 'Glacialis' and Mentha piperita 'Swiss' (Fig. 2). These results correspond with the report of Rubinskiene et al. (2015). They reported

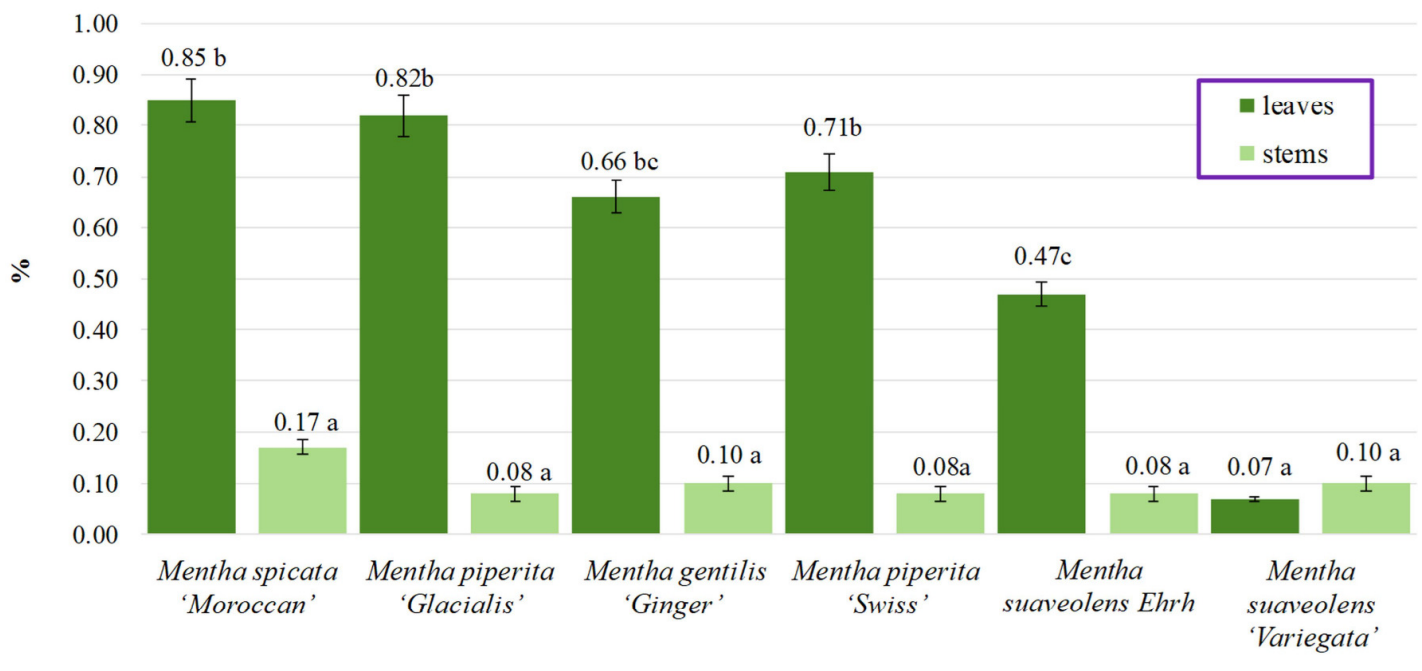

Species/variety

Fig. 1. Essential oil content in different parts of various species and variety mints $(\%) .{ }^{*}$ Values (means \pm standard deviations) with different index letters are significantly different $(\mathrm{P}<0.05)$

Table 3. Chemical composition of different parts of various species and variety mints (\%)

\begin{tabular}{|c|c|c|c|c|}
\hline Species/variety & Part of plant & Dry matter & Crude ash & Crude fiber \\
\hline \multirow{2}{*}{ Mentha spicata 'Moroccan' } & Leaves & $21.72 \pm 0.03 b^{*}$ & $10.17 \pm 0.028 \mathrm{~g}$ & $10.77 \pm 3.08 \mathrm{a}$ \\
\hline & Stems & $27.53 \pm 0.34 \mathrm{de}$ & $5.76 \pm 0.174 \mathrm{e}$ & $40.61 \pm 2.02 c$ \\
\hline \multirow{2}{*}{ Mentha piperita 'Glacialis' } & Leaves & $26.60 \pm 0.12 \mathrm{~d}$ & $8.79 \pm 0.043 b$ & $11.83 \pm 0.49 \mathrm{a}$ \\
\hline & Stems & $27.28 \pm 0.32 \mathrm{de}$ & $6.90 \pm 0.115 a$ & $43.83 \pm 0.20 \mathrm{~d}$ \\
\hline \multirow{2}{*}{ Mentha gentilis 'Ginger' } & Leaves & $24.74 \pm 0.08 c$ & $10.93 \pm 0.080 \mathrm{c}$ & $10.03 \pm 0.57 \mathrm{a}$ \\
\hline & Stems & $28.63 \pm 0.58 \mathrm{e}$ & $6.68 \pm 0.075 a$ & $33.41 \pm 0.85 b$ \\
\hline \multirow{2}{*}{ Mentha piperita 'Swiss' } & Leaves & $26.98 \pm 2.58 \mathrm{~d}$ & $10.66 \pm 0.019 \mathrm{~h}$ & $12.37 \pm 0.40 \mathrm{a}$ \\
\hline & Stems & $32.32 \pm 0.41 \mathrm{f}$ & $5.41 \pm 0.072 \mathrm{~d}$ & $51.57 \pm 1.68 \mathrm{e}$ \\
\hline \multirow{2}{*}{ Mentha suaveolens Ehrh } & Leaves & $20.93 \pm 0.12 b$ & $10.92 \pm 0.018 \mathrm{c}$ & $11.29 \pm 0.44 \mathrm{a}$ \\
\hline & Stems & $20.70 \pm 0.34 b$ & $8.17 \pm 0.168 \mathrm{f}$ & $42.18 \pm 3.05 \mathrm{~cd}$ \\
\hline \multirow{2}{*}{ Mentha suaveolens 'Variegata' } & Leaves & $15.82 \pm 0.17 \mathrm{a}$ & $12.15 \pm 0.186 \mathrm{i}$ & $12.52 \pm 0.32 \mathrm{a}$ \\
\hline & Stems & $16.19 \pm 0.29 a$ & $8.66 \pm 0.116 b$ & $32.72 \pm 1.07 \mathrm{~b}$ \\
\hline
\end{tabular}

${ }^{*}$ Values: (means \pm standard deviations) in the column with different index letters are significantly different $(\mathrm{P}<0.05)$ 


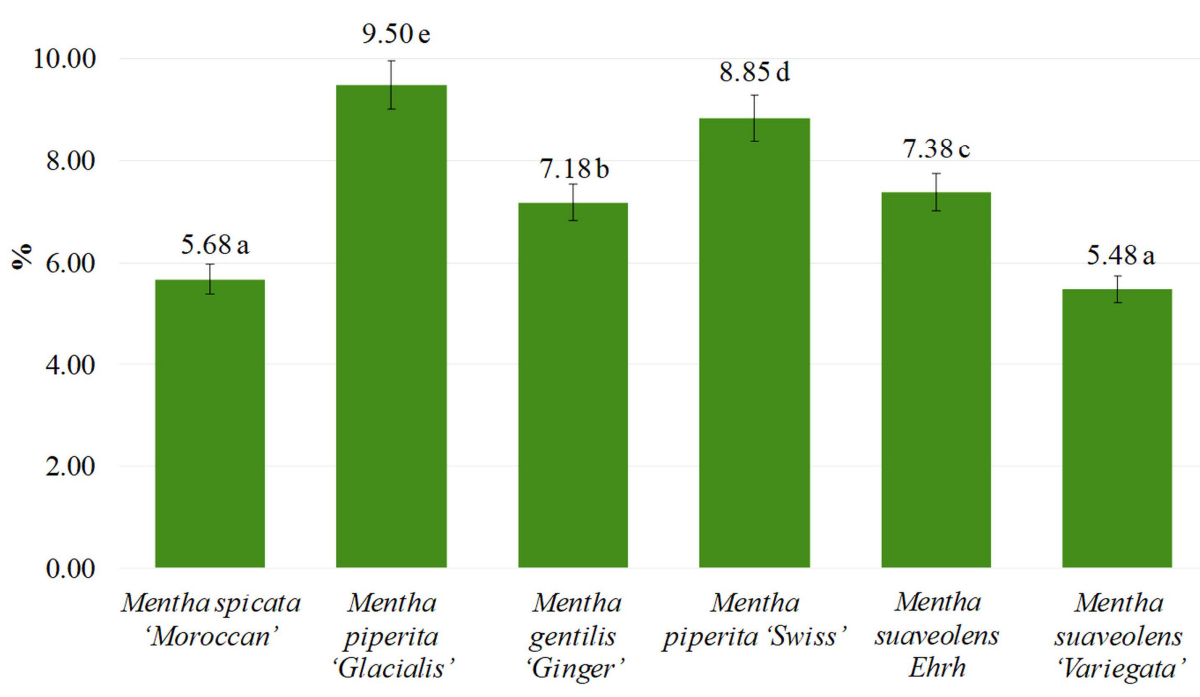

Species / variety

Fig. 2. Amount of soluble solids in various species and variety mint leaves (\% FW)

*Note Values: (means \pm standard deviations) with different index letters are significantly different $(\mathrm{P}<0.05)$

that in Mentha piperita L. the content of soluble solids was $10.6 \%$. The lowest content of soluble solids was determined in Mentha suaveolens Ehrh and Mentha spicata 'Maroccan'. The amount of soluble solids in plants relates not only on climatic conditions, plants species but also on the variety. Two varieties of Mentha suaveolens showed the difference in the content of soluble solids equal to 1.9 percent units (Fig. 2).

Ascorbic acid is one of the most important water soluble vitamins with strong antioxidant activity. It also plays a primary role in the formation of collagen, which is important for the growth and repair of body tissue cells, gums, blood vessels, teeth and bones. In addition, ascorbic acid can regenerate vitamin $\mathrm{E}$ from its oxidized form (Lykkesfeldt et al., 2014). The highest amounts of ascorbic acid were determined in Mentha spicata 'Moroccan' (4.57

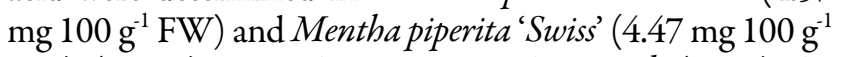
FW) (Fig. 3). According to Curutchet et al. (2014) the content of ascorbic acid in M. piperita was $140 \mu \mathrm{g} \mathrm{kg}^{-1} \mathrm{FW}$, while in M. spicata $480 \mu \mathrm{g} \mathrm{kg}^{-1} \mathrm{FW}$. Rubinskienè et al. (2015) found that ascorbic acid content in M. piperita ranged from 25.2 to $26.1 \mathrm{mg} 100 \mathrm{~g}^{-1} \mathrm{FW}$. It was found that the amount of ascorbic acid in all mints was very similar and

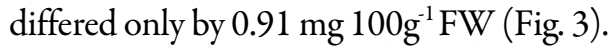

The plant colour is dependent on materials, which contain a bio-chrome (pigment) which either absorbs or reflects different wavelengths of light. The absorbed light is split into pigments and reflected light is visible as the colour. The pigments are classified into several groups, i.e. chlorophylls, carotenoids, flavonoids, betalaines (Mlodzinska, 2009).

Chlorophyll $a$ dominated in mint leaves as in stems. The highest amount of chlorophyll $a$ was determined in Mentha piperita 'Glacialis' and the 5.24 times least content in Mentha piperita 'Swiss' leaves (Table 4). Amount of chlorophyll $b$ in Mentha piperita 'Glacialis' was 6.6-times higher than in Mentha piperita 'Swiss'. Total amount of chlorophylls in leaves was the highest in Mentha piperita
'Glacialis' and Mentha suaveolens 'Variegata', while in Mentha piperita 'Swiss' by $1.06 \mathrm{mg} \mathrm{g}^{-1}$ less. Grzeszczuk and Jadczak (2009) observed that amount of chlorophyll $a$ in mint was equal to $1.435 \mathrm{mg} \mathrm{g}^{-1} \mathrm{FW}$ and chlorophyll $b$ equal to $0.421 \mathrm{mg} \mathrm{g}^{-1} \mathrm{FW}$. Chlorophylls $a$ and $b$ usually are represented in plants at the ratio of 3.00 (Chen and Chen, 1993). Average ratio of chlorophylls $a$ and $b$ in investigated mint leaves was equal to 2.78. According to Grzeszczuk and Jadczak (2009), in mints without separation of leaves and stems the ratio was equal to 3.40. Straumite et al. (2015) reported that this ratio ranged in investigated mint leaves from 3.79 till 7.64. Our research data show that amount of ascorbic acid strongly negatively correlated with total amount of chlorophyll a $(0,729)$ in mints leaves. As ascorbic acid is synthesized by plant mitochondria and accumulated in chloroplast it participates in photosynthesis (Senn et al., 2016). According to Del Longo et al. (1997) possibly that in light conditions chlorophyll loss by ascorbate is due to increase in lipid peroxidation, membrane alteration and $\mathrm{OH}$ production and its effects on the pigment.

Carotenoids content in the Mentha plants differed in relation to species. In Mentha piperita 'Glacialis' leaves the amount of carotenoids was the highest and in Mentha piperita 'Swiss' the least (Table 4). Different relation was found in stems, where the content of carotenoids was the highest in Mentha suaveolens Ehrh and the least in Mentha gentilis L. 'Ginger' (Table 4). In Mentha spicata 'Moroccan' stems and leaves the amount of carotenoids was equal to

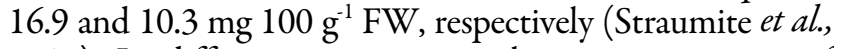
2015). In different mint species the average amount of carotenoids was equal to $0.567 \mathrm{mg} \mathrm{g}^{-1}$ (Grzeszczuk and Jadczak, 2009).

According to Rubinskiene et al. (2015), the amount of carotenoids in Mentha piperita L. cultivar leaves was equal

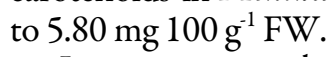

In mint stems the highest amount of chlorophyll $a$ content was observed in Mentha suaveolens Ehrh. and the 
least in Mentha gentilis 'Ginger' (Table 4). Average ratio between chlorophyll $a$ and $b$ in stems was equal to 2.83 , a little higher than in the leaves. The highest content of photosynthetic pigments was found in Mentha suaveolens Ehrh stems (Table 4).

The results of correlation analysis showed that there are positive strong correlation between chlorophyll $a$ and carotenoids content in leaves (0.984) and stems (0.993). Miri et al. (2015) determined strong correlation between amount of carotenoids and chlorophyll $a(0.870)$ and moderate between chlorophyll $a$ and essential oil (0.630) content in thymus plant. In investigated mints plants strong positive correlation was observed between the total amount of chlorophylls and carotenoids (0.982), but no any relation was not found between amount of chlorophylls and essential oil.

\section{Physical parameters}

Colour of plants depends on the amount of pigments, their decomposition and ongoing enzymatic darkening. The highest $\mathrm{L}^{*}$ (lightness) value was found for Mentha suaveolens 'Variegata' and the lowest for Mentha spicata 'Moroccan' leaves (Table 5). Mentha piperita 'Swiss' was the greenest ( $\mathrm{a}^{*}$ value was the lowest) and the least green was Mentha gentilis

Table 4. Amounts of photosynthetic pigments in various species and variety mints $\left(\mathrm{mg} \mathrm{g}^{-1} \mathrm{FW}\right)$

\begin{tabular}{ccccccc}
\hline Species/variety & Part of plant & Ch a & Ch b & Ch total & Ratio a b \\
\hline Mentha spicata & Leaves & $0.640 \pm 0.028 \mathrm{~d}^{*}$ & $0.225 \pm 0.011 \mathrm{ce}$ & $0.866 \pm 0.039 \mathrm{de}$ & $2.844 \pm 0.056 \mathrm{bd}$ & $0.226 \pm 0.010 \mathrm{~g}$ \\
'Moroccan' & Stems & $0.237 \pm 0.021 \mathrm{bc}$ & $0.078 \pm 0.003 \mathrm{ab}$ & $0.315 \pm 0.023 \mathrm{ab}$ & $3.053 \pm 0.459 \mathrm{~cd}$ & $0.082 \pm 0.001 \mathrm{abd}$ \\
& Leaves & $0.917 \pm 0.010 \mathrm{~h}$ & $0.376 \pm 0.014 \mathrm{~g}$ & $1.293 \pm 0.020 \mathrm{~g}$ & $2.450 \pm 0.186 \mathrm{a}$ & $0.310 \pm 0.005 \mathrm{~h}$ \\
Mentha piperita 'Glacialis' & Stems & $0.184 \pm 0.011 \mathrm{ab}$ & $0.066 \pm 0.002 \mathrm{ab}$ & $0.249 \pm 0.013 \mathrm{ab}$ & $2.799 \pm 0.252 \mathrm{~b}$ & $0.062 \pm 0.002 \mathrm{abc}$ \\
& Leaves & $0.519 \pm 0.021 \mathrm{df}$ & $0.163 \pm 0.006 \mathrm{~cd}$ & $0.682 \pm 0.027 \mathrm{~cd}$ & $3.178 \pm 0.120 \mathrm{c}$ & $0.160 \pm 0.006 \mathrm{ef}$ \\
Menthagentilis 'Ginger' & Stems & $0.067 \pm 0.010 \mathrm{a}$ & $0.026 \pm 0.006 \mathrm{a}$ & $0.093 \pm 0.016 \mathrm{a}$ & $2.645 \pm 0.190 \mathrm{ab}$ & $0.024 \pm 0.001 \mathrm{c}$ \\
& Leaves & $0.175 \pm 0.006 \mathrm{ab}$ & $0.057 \pm 0.002 \mathrm{ab}$ & $0.233 \pm 0.007 \mathrm{ab}$ & $3.046 \pm 0.162 \mathrm{~cd}$ & $0.053 \pm 0.002 \mathrm{ac}$ \\
Menthapiperita 'Swiss' & Stems & $0.197 \pm 0.014 \mathrm{abc}$ & $0.074 \pm 0.002 \mathrm{ab}$ & $0.270 \pm 0.016 \mathrm{ab}$ & $2.678 \pm 0.316 \mathrm{ab}$ & $0.069 \pm 0.002 \mathrm{ab}$ \\
Mentha suaveolens Ehrh & Leaves & $0.436 \pm 0.224 \mathrm{ef}$ & $0.185 \pm 0.083 \mathrm{c}$ & $0.621 \pm 0.305 \mathrm{c}$ & $2.485 \pm 0.680 \mathrm{a}$ & $0.121 \pm 0.050 \mathrm{de}$ \\
Mentha suaveolens & Stems & $0.676 \pm 0.220 \mathrm{dg}$ & $0.287 \pm 0.088 \mathrm{ef}$ & $0.963 \pm 0.308 \mathrm{ef}$ & $2.516 \pm 0.286 \mathrm{a}$ & $0.176 \pm 0.048 \mathrm{f}$ \\
'Variegata' & Leaves & $0.819 \pm 0.010 \mathrm{gh}$ & $0.307 \pm 0.011 \mathrm{fg}$ & $1.125 \pm 0.015 \mathrm{fg}$ & $2.685 \pm 0.210 \mathrm{ab}$ & $0.243 \pm 0.007 \mathrm{~g}$ \\
\hline
\end{tabular}

${ }^{*}$ Note Values: (means \pm standard deviations) in the column with different index letters are significantly different $(\mathrm{P}<0.05)$

Table 5. Colour characteristics of various species and variety mint leaves

\begin{tabular}{|c|c|c|c|c|c|}
\hline Species / variety & $\mathrm{L}^{*}$ (lightness) & $\mathrm{a}^{*}(\mathrm{red} /$ green $)$ & $\mathrm{b}^{*}$ (yellow/blue) & $\mathrm{C}^{*}($ chroma $)$ & $\mathrm{h}^{\circ}$ (hue angle) \\
\hline Mentha spicata 'Moroccan' & $28.77 \pm 0.71 \mathrm{a}^{*}$ & $-7.30 \pm 0.30 b$ & $16.98 \pm 0.85 b$ & $18.49 \pm 4.35 c$ & $113.29 \pm 1.38 \mathrm{cde}$ \\
\hline Mentha piperita 'Glacialis' & $31.58 \pm 2.87 \mathrm{abc}$ & $-6.56 \pm 0.11 c$ & $16.73 \pm 0.68 b$ & $17.97 \pm 2.04 \mathrm{bc}$ & $111.43 \pm 0.60 \mathrm{c}$ \\
\hline Mentha gentilis 'Ginger' & $33.50 \pm 1.27 \mathrm{bc}$ & $-3.92 \pm 0.63 e$ & $16.62 \pm 0.61 b$ & $17.07 \pm 5.65 b$ & $103.22 \pm 1.60 \mathrm{a}$ \\
\hline Mentha piperita 'Swiss' & $33.51 \pm 1.79 \mathrm{bc}$ & $-8.20 \pm 0.17 a$ & $20.17 \pm 0.63 c$ & $21.77 \pm 3.40 \mathrm{~d}$ & $112.13 \pm 0.24 \mathrm{~cd}$ \\
\hline Mentha suaveolens Ehrh & $35.06 \pm 3.74 \mathrm{c}$ & $-7.25 \pm 0.64 b$ & $15.97 \pm 0.68 \mathrm{~b}$ & $17.54 \pm 9.57 \mathrm{bc}$ & $114.39 \pm 1.78 \mathrm{e}$ \\
\hline Mentha suaveolens 'Variegata' & $41.62 \pm 4.83 \mathrm{~d}$ & $-4.13 \pm 0.36 \mathrm{e}$ & $14.01 \pm 1.97 \mathrm{a}$ & $14.62 \pm 3.44 \mathrm{a}$ & $106.72 \pm 2.80 \mathrm{~b}$ \\
\hline
\end{tabular}

${ }^{*}$ Note Values: (means \pm standard deviations) in the column with different index letters are significantly different $(\mathrm{P}<0.05)$

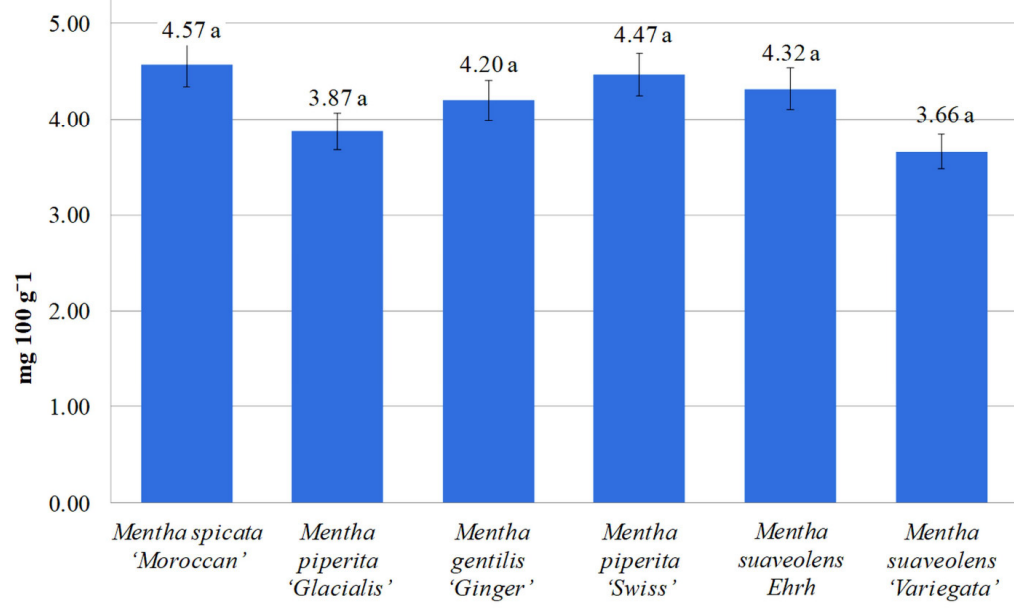

Fig. 3. Ascorbic acid content in various species and variety mint leaves $\left(\mathrm{mg} 100 \mathrm{~g}^{-1} \mathrm{FW}\right)$

${ }^{*}$ Note Values (means \pm standard deviations) with different index letters are significantly different $(\mathrm{P}<0.05)$ 
98

L. 'Ginger' (the highest $\mathrm{a}^{*}$ and the lowest $\mathrm{h}^{\circ}$ ). The most intensive green colour was characteristic to Mentha suaveolens Ehrh and Mentha spicata 'Moroccan' plants. Mentha suaveolens 'Variegata' plant leaves were the least yellow (the lower $b^{*}$ value). The results correspond with the highest amount of chlorophyll $a$, which is bluish-green in this mint species leaves (Table 4) and (Table 5). Colour saturation or intensity was the highest in Mentha piperita 'Swiss' and the lowest in Mentha suaveolens 'Variegata', between other investigated plants difference of colour saturation was very slight.

\section{Conclusions}

The highest amounts of essential oil were determined in Mentha spicata 'Moroccan' and Mentha piperita 'Glacialis' leaves. Essential oil content in stems did not depend on mint species and variety. Plant parts differ significantly in respect of chemical composition. Dry matter content was higher in mint leaves comparing with the stems, as well as the content of ash. Crude fibre content did not differ significantly in leaves of all investigated mints and was 3.6times lower than in the stems. The highest soluble solids content was characteristic to Mentha piperita plants, while the least to Mentha suaveolens. Content of photosynthetic pigments depends on Mentha species and varieties. Average ratio between chlorophyll $a$ and $b$ for the leaves was equal to 2.78, while for the stems - equal to 2.83. In respect of colour parameters, the lightest was Mentha suaveolens 'Variegata' leaves, the darkest Mentha spicata 'Moroccan' leaves and the greenest Mentha piperita 'Swiss' leaves. The highest in length and most biomass waste generating plants was $M$. piperita 'Swiss'. Therefore, it is likely that their use as alternative fibrous biomass plant would be the most productive.

\section{Acknowledgements}

The authors are thankful to Milnora and Linas Pšibišauskai who have contributed to the research with advice and research materials.

\section{References}

Božović M, Pirolli A, Ragno R (2015).Mentha suaveolens Ehrh. (Lamiaceae) essential oil and its main constituent piperitenone oxide. Biological Activities and Chemistry 20:8605-8633.

Britton G, Liaaen-Jensen S, Pfander H (2004). Carotenoids handbook. Basel, Switzerland pp 50-563.

Capecka E, Mareczek A, Leja M (2005). Antioxidant activity of fresh and dry herbs of some Lamiaceae species. Food Chemistry 93(2):223-226.

Chand S, Patra NK, Anwar M, Patra DD (2004). Agronomy and uses of menthol mint Mentha arvensis - Indian perspective. Proceedings of the Indian National Science Academy Part B, Biological Sciences 70(3):269-297.

Chen BH, Chen YY (1993). Stability of chlorophylls and carotenoids in sweet potato leaves during microwave cooking. Journal of Agricultural
andFoodChemistry41(8):1315-1320.

Curutchet A, Dellacassa E, Ringuelet JA, Chaves AR, Vina SZ (2014). Nutritional and sensory quality during refrigerated storage of fresh-cut mints (Mentha $\times$ piperita and M. spicata). Food Chemistry 143:231238.

Del Longo OT, Koroch AR, Trippi VS (1997). The role of ascorbic acid in the preservation or degradation of chlorophyll in oat leaves. Agriscientia 14:11-17.

Devi KM, Palod J, Dar AH, Shekhar S (2018). Effect of Feeding Graded Levels of Pudina (Mentha arvensis L.) leaf powder on egg quality Traits in Laying Hen. International Journal of Current Microbiology and Applied Sciences 7(03):756-761.

Doymaz I (2006). Thin - layer drying behaviour of mint leaves. Journal of FoodEngineering 74(3):370-375.

Elansary HO, Ashmawy NA (2013). Essential oils of mint between benefits and hazards.Journal of Essential Oil BearingPlants 16(4):429-438.

Fardad K, Najafi B, Ardabili SF, Mosavi A, Shamshirband S, Rabczuk T (2018). Biodegradation of medical plants waste in an anaerobic digestion reactor for biogass production. Computers, Materials and Continua 55(3):381-392.

Gaur S, Shivhare US, Sarkar BC, Ahmed J (2007). Thermal chlorophyll degradation kinetics of mint leaves puree. International Journal of Food Properties 10(4):853-865.

Godin B, Lamaudiere S, Agneessens R, Schmit T, Goffart JP, Stilmant D, Gerin PA, Delcarte J (2013). Chemical composition and biofuel potentials of a wide diversity of plant biomasses. Energy Fuels 27(5):2588-2598.

Golparvar AM, Hadipanah A (2016). Diversity in chemical composition and yield of essential oil from two Mentha species. Genetika 48(3):11011110.

Gond V, Depury DGG, Veroustraete F, Ceulemans R (2012). Seasonal variations in leaf area index, leaf chlorophyll, and water content; scalingup to estimate fapar and carbon balance in a multilayer, multispecies temperate forest. Tree Physiology 19(10):673-679.

Grzeszczuk M, Jadczak D (2009). Estimation of biological value of some species of mint (Mentha L.).Herba Polonica 5(3):193-199.

Gupta AK, Mishra R, Singh AK, Srivastava A, Lal RK (2017). Genetic variability and correlations of essential oil yield with agro-economic traits in Mentha species and identification of promising cultivars. Industrial Crops and Products 95:726-734.

Hussain AI, Anwar F, Nigam PS, Ashraf M, Gilani AH (2010). Seasonal variation in content, chemical composition and antimicrobial and cytotoxic activities of essential oils from four Mentha species. Journal of the Science of Food and Agriculture 90(11):1827-36.

Jacob ME, Fox JT, Reinstein SL, Nagaraja TG (2008). Antimicrobial susceptibility of foodborne pathogens in organic or natural production systems: an overview. Foodborne Pathogens and Disease 5:721-730.

Kahkashan P, Bokhari N, Siddique I, Siddiqui I (2016). Influence of Soil Type on the Growth Parameters, Essential Oil Yield and Biochemical Contents of Mentha arvensis L. Journal of Essential Oil Bearing Plants 19(1):76-81.

KumarJK, Sinha AK (2004). Resurgence of natural colorants: a holistic view. Natural Product Letters 18(1):59-84. 
Lin CSK, Koutinas AA, Stamatelatou K, Mubofu EB, Matharu AS, Kopsahelis N, Luque R(2014). Current and future trends in food waste valorization for the production of chemicals, materials and fuels: A global perspective. Biofuels, Bioproducts and Biorefining 8:686-715.

Lst En Iso 6571 (2013). Spices, condiments and herbs-determination ovolatile oil content (hydrodistillation method). Lietuvos standartizacijos departamentas. 13.

Lst Iso 6557-2 (2000). Vaisiai, daržovès ir jų gaminiai. Askorbo rūgšties kiekio nustatymas. 2 dalis. Iprastiniai metodai (tpt ISO 6557-2:1984 [E]). 6.

Lykkesfeldt J, Michels AJ, Frei B (2014). Vitamin C. Advances in Nutrition 5(1):16-18.

Mahboobeh Z, Morteza AS, Mryam T, Reza (2014). Effects of organic and chemical fertilizers on quantitative and qualitative characteristics of peppermint (Mentha piperita L.). International Journal of Agriculture and CropSciences 7(5):237-244.

McGuire RG (1992). Reporting of objective color measurements. HortScience 27(12):12541255.

Methodenbuch (1983-1999). Band III. Die chemishe Untersuchung von Futtermitteln. Verlag-Darmstadt.

MiriSM, Ahmadi S, Moradi P (2015). Influence of salicylic acid and citric acid on the growth, biochemical characteristics and essential oil content of thyme (Thymus vulgaris L.). Journal of Medicinal Plants and By-products 2:141-146.

Mlodzinska E (2009). Survey of plant pigments: Molecular and environmental determinants of plant colors. Acta Biologica CracoviensiaSeries Botanica 51(1):7-16.

Nambara E, Marion-Poll A (2005) Abscisic acid biosynthesis and catabolism. Annual Review of Plant Biology 56:165-185.

Niyogi K (2000). Safety valves for photosynthesis. Current Opinions in Plant Biology 3:455-460.

Prakash OM, Naik M, Katiyar R, Naik S, Kumar D, Maji D, ... Rout PK (2018). Novel process for isolation of major bio-polymers from $M e n t h a$ arvensis distilled biomass and saccharification of the isolated cellulose to glucose. Industrial Crops and Products 119:1-8.

Raja R (2012). Medicinally potential plants of Labiatae (Lamiaceae) Family: An overview.Journal of Medicinal Plant 6(3):203-213.

Reis IAO, Santos SB, Santos LA, Oliveira N, Freire MG, Pereira JFB, Lima AS (2012). Increased significance of food wastes: Selective recovery of added-value compounds. Food Chemistry 135:2453-2461.

Roselló-Soto E, Koubaa M, Moubarik A, Lopes RP, SaraivaJA, Boussetta N, Barba FJ (2015). Emerging opportunities for the effective valorization of wastes and by-products generated during olive oil production process: Nonconventional methods for the recovery of high-added value compounds. Trends in Food Science and Technology 45:296-310.
Rubinskienė M, Viškelis P, Dambrauskienė E, Viškelis J, Karklelienė R (2015). Effect of drying methods on the chemical composition and colour of peppermint (Mentha $\times$ piperita L.) leaves. Zemdirbyste Agriculture 102(2):223-228.

Saeed K, Pasha I, Bukhari H, Masood S, Butt MS, Iftikhar T, Shujah U, Ud D (2014). Compositional profiling of Menthapiperita. Pakistan Journal of FoodSciences 24(3):151-156.

Senge MO (1993). Recent advances in the biosynthesis and chemistry of chlorophylls. Photochemistry and Photobiology 57:189-206.

Senn ME, Grozeff GEG, Alegre ML, Barrile F, De Tullio MC, Bartoli CG (2016). Effect of mitochondrial ascorbic acid synthesis on photosynthesis. Plants Physiology and Biochemistry 104:29-35.

Shahidi F, Ambigaipalan P (2015). Phenolics and polyphenolics in foods, beverages and spices: Antioxidant activity and health effects - A review. Journal of Functional Foods 18:820-897.

Skowera B, Puła J (2004). Pluviometric extreme conditions in spring season in Poland in theyears 1971-2000. Acta Agrophysica3(1):171-177.

Straumite E, Kruma Z, Galoburda R (2015). Pigments in mint leaves and stems. Agronomy Research 13(4):11041111.

Sulieman AME, Abdelrahman SE, Abdel Rahim AM (2011). Phytochemical analysis of local spearmint (Mentha spicata) leaves and detection of the antimicrobial activity of its oil. Journal of Microbiology Research 1(1):1-4.

Triphaty V, Basak BB, Varghes TS, Saha A (2015). Residues and contaminants in medicinal herbs - A review. Phytochemistry Letters 14:67-78.

Tucker AO (2007). Mentha: Economic Uses. In:LawrenceBM(Ed). Mint, the genus Mentha. Boca Raton, Florida, United States of America pp 519-522.

Wellburn AR (1994). The spectral determination of chlorophylls a and b, as well as total carotenoids, using various solvents with spectrophotometers of different resolution. Plant Physiology 144(3):307-313.

Who (2011). Quality control methods for herbal materials. World Health Organization. Geneva pp 51-89.

Young JE., Zhao X, Carey EE, Welti R, Yang S, Wang W (2005). Phytochemical phenolics in organically grown vegetables. Molecular Nutrition and Food Research 49:1136-1142.

Zhang W, Wang SH (2001). Antioxidant activity compounds in selected herbs. Journal of Agricultural and Food Chemistry 49(11):5165-5170.

Zollinger H (1991). Color chemistry: Synthetic, properties and applications of organic dyes and pigments. $\mathrm{VCH}$, Weinheim, Germany. 